Dinamika Sosial Budaya, Vol 22, No. 2, Desember 2020, pp 174-183

p-ISSN: 1410-9859\& e-ISSN: 2580-8524

http://journals.usm.ac.id/index.php/jdsb

\title{
ANALISIS PENILAIAN KINERJA KEUANGAN PERUSAHAAN BERBASIS DU PONT SYSTEM
}

\author{
Tri_Rinawati ${ }^{1}$, Asih Niati ${ }^{2}$, Yohanes Suhardjo ${ }^{3}$ \\ Fakultas Ekonomi Universitas Semarang \\ rinaoshin@gmail.com¹, $\underline{\text { asihniati@gmail.com² }}$, yohanes_suhardjo@yahoo.com ${ }^{3}$
}

\begin{abstract}
ABSTRAKSI
Penelitian bertujuan mengetahui penilaian kinerja keuangan perusahaan untuk saham Jakarta Islamic Index (JII) dan saham Index LQ45 dengan menggunakan Du Pont System dan mengetahui perbedaan kinerja keuangan perusahaan untuk saham Jakarta Islamic Index (JII) dengan Index LQ45. Populasinya adalah saham Jakarta Islamic Index berjumlah 30 emiten dan Index LQ45 berjumlah 45 emiten. Teknik pengambilan sampel menggunakan metode Purposive Sampling. Teknik analisa yang digunakan yakni Du Pount System, uji asumsi klasik, dan Uji Independent Sample t test. Hasil perhitungan analisa Du Pont periode tahun 2014 - 2018 untuk Indeks Saham JII rata-rata ROI berada di bawah rata-rata industri hal ini menunjukkan bahwa kinerja perusahaan dalam menghasilkan laba kurang baik dan rata-rata ROE lebih dari satu hal ini menunjukkan semakin efektif dan efisien penggunaan ekuitas perusahaan untuk menghasilkan pendapatan. Hasil perhitungan analisa Du Pont periode tahun 2014 - 2018 untuk Indeks Saham LQ45 diperoleh rata-rata ROI berada di bawah rata-rata industri yang menunjukkan bahwa kinerja perusahaan dalam menghasilkan laba kurang baik, dan rata-rata ROE lebih dari satu hal ini menunjukkan semakin efektif dan efisien penggunaan ekuitas perusahaan untuk menghasilkan pendapatan. Hasil penelitian disimpulkan bahwa terdapat perbedaan yang signifikan antara kinerja keuangan yang diukur dengan ROI untuk jenis saham JII dan LQ45 yang menggambarkan terdapat perbedaan laba bersih yang didapatkan perusahaan dari seluruh kekayaan yang dimilikinya. Sedangkan kinerja keuangan yang diukur dengan ROE untuk jenis saham JII dan LQ45 tidak terdapat perbedaan yang signifikan yang menunjukkan bahwa tidak terdapat perbedaan laba bersih setelah pajak yang dihasilkan perusahaan dan tidak terdapat perbedaan efisiensi penggunaan modal sendiri oleh perusahaan
\end{abstract}

Kata Kunci : Du Pount System, Kinerja Keuangan

\section{Abstract.}

This study aims to determine the company's financial performance appraisal for Jakarta Islamic Index (JII) stocks and LQ45 Index shares using the Du Pont System and to find out the differences in company financial performance for Jakarta Islamic Index (JII) stocks with the LQ45 Index.

The population is the shares of the Jakarta Islamic Index totaling 30 issuers and the LQ45 Index totaling 45 issuers. The sampling technique used purposive sampling method. The analysis technique used is the Du Pount System, classical assumption test, and Independent Sample t test. The results of the Du Pont analysis for the period 2014 - 2018 for the JII Stock Index, the average ROI is below the industry average, this shows that the company's performance in generating profits is not good and the average ROE is more than one, this shows that it is more effective and 
Dinamika Sosial Budaya, Vol 22, No. 2, Desember 2020, pp 174-183

p-ISSN: 1410-9859\& e-ISSN: 2580-8524

http://journals.usm.ac.id/index.php/jdsb

efficient use of company equity to generate revenue. The results of the Du Pont analysis for the period 2014 - 2018 for the LQ45 Stock Index, it is found that the average ROI is below the industry average which indicates that the company's performance in generating profits is not good, and the average ROE of more than one thing shows that it is more effective and efficient use of company equity to generate revenue. The results of the study concluded that there is a significant difference between financial performance as measured by ROI for the types of shares JII and LQ45 which illustrates that there are differences in net income obtained by the company from all its assets. Meanwhile, there is no significant difference in financial performance as measured by ROE for the types of shares JII and LQ45, which indicates that there is no difference in net profit after tax generated by the company and there is no difference in the efficiency of using its own capital by the company.

Keyword: Du Pount System, Financial Performance 
Dinamika Sosial Budaya, Vol 22, No. 2, Desember 2020, pp 174-183

p-ISSN: 1410-9859\& e-ISSN: 2580-8524

http://journals.usm.ac.id/index.php/jdsb

\section{PENDAHULUAN}

Indeks saham adalah salah satu metode untuk mengukur pergerakan kumpulan saham secara keseluruhan ataupun atas saham-saham dengan ktriteria tertentu. Di Indonesia dikenal dengan IHSG (Indeks Harga Saham Gabungan) yang mempresentasikan pergerakan seluruh saham yang tercata di Bursa Efek Indonesia yang per Desember 2017 memiliki anggota sebanyak 570 perusahaan. Indeks saham umumnya digunakan oleh investor sebagai indicator dalam melihat pergerakan bursa dan sebagai pembanding untuk menilai kinerja investasi yang berkaitan dengan saham. Indeks juga dapat digunakan sebagai acuan untuk menilai baik buruknya kinerja investasi. Jakarta Islamic Index (JII) merupakan indeks yang memiliki pergerakan 30 saham syariah yang memiliki kapitalisasi pasar terbesar dengan transaksi terlikuid.

Syariah di pasar modal Indonesia identic dengan Jakarta Islamic Index. Dalam sepekan terakhir, JII sempat mencetak yang lebih baik dari pada Indeks Harga Saham Gabungan (IHSG). Data dihimpun menunjukkan JII mencatatkan kenaikan 2,12\%. Sedangkan IHSG hanya mampu mengalami kenaikan sebesar 1,98\%. Faktor eksternal mempengaruhi kinerja saham big caps dan small caps di IHSG yang terdiri dari ratusan emiten. Anggota JII terdiri dari 30 emiten, maka tidak terlalu terpukul atas sentiment eksternal seperti IHSG. Penggerak JII berasal dari beberapa sector, misalnya sector manufaktur dan industry penggeraknya adalah ASII. Dari sector infrastuktur dan komunikasi ada TLKM sedangkan dari sector tambang ada PGAS. JII mencatatkan kinerja yang lebih rendah dari pada IHSG.

Mayoritas emiten anggota indeks LQ45 mencatatkan kinerja positif hingga paruh waktu tahun 2019, namun masih ada perlambatan di balik positifnya kinerja tersebut. Positifnya kinerja tercermin dari total pendapatan dan laba bersih masingmasing emiten di setiap sektor.

Analisis rasio keuangan adalah merupakan suatu alat analisa yang digunakan oleh perusahaan untuk menilai kinerja keuangan berdasarkan data perbandingan masing-masing pos yang terdapat di laporan keuangan seperti Laporan Neraca, Rugi Laba, dan Arus Kas dalam periode tertentu. Laporan keuangan bertujuan untuk memberikan gambaran informasi mengenai posisi keuangan dan kinerja perusahaan yang dapat dijadikan dalam mengambil keputusan. Analisa laporan keuangan dilakukan dengan menganalisa masing-masing pos yang terdapat di dalam laporan keuangan dalam bentuk rasio posisi keuangan dengan tujuan agar dapat memaksimalkan kinerja perusahaan untuk masa yang akan datang.

Tujuan utama analisis laporan keuangan adalah sebagai alat barometer untuk melakukan proyeksi posisi keuangan di masa yang akan datang, me-review kondisi perusahaan, alat ukut untuk melakukan efisiensi di semua departemen perusahaan. Metode yang digunakan sebagai tolak ukur untuk menilai posisi keuangan perusahaan antara lain metode analisa pertumbuhan, metode trend dan Indeks, dan metode analisis rasio.

Salah satu alat analisa laporan keuangan adalah Du Pont System, yaitu rasio keuangan yang digunakan untuk menganalisis kemauan perusahaan untuk meningkatkan pengembalian atas ekuitas atau Return On Invesment (ROI). Du Pont System merupakan alat analisis yang digunakan untuk menganalisis laba dari perusahaan atau bisnis. Perhitungan Du Pont System mempunyai satu dasar indicator yang fundamental yaitu Return On Invesment (ROI). Pada indikator ROE, ada tiga indikator keuangan yang mempengaruhinya. Indikator tersebut adalah efisiensi operasi, efisiensi penggunaan asset dan leverage 
Dinamika Sosial Budaya, Vol 22, No. 2, Desember 2020, pp 174-183

p-ISSN: 1410-9859\& e-ISSN: 2580-8524

http://journals.usm.ac.id/index.php/jdsb

keuangan. Efisiensi operasi diwakili oleh margin laba bersih atau laba bersih dibagi dengan total penjualan atau pendapatan, efisiensi penggunaan asset diukur dengan rasio perputaran asset, sedangkan leverage diukur dengan pengganda ekuitas.

Penelitian yang dilakukan Lesmana (2013), menjelaskan bahwa penilaian kinerja suatu perusahaan dapat dilihat bail melalui aspek keuangan maupun aspek non keuangan. Penelitiannya khusus mengukur kinerja keuangan perusahaan dengan memfokuskan pada Du Pont System. Sistem ini membagi kinerja keuangan ke dalam tiga komponen yakni margin laba bersih, tingkat pengembalian asset dan tingkat pengembalian atas ekuitas atau modal. Hasil penelitiannya disimpulkan bahwa kinerja perusahaan Bank Republik Indonesia (Persero) Tbk (BBRI), Bank Central Asia Tbk (BBCA), Bank Mandiri (Persero) Tbk (BMRI), Bank Negara Indonesia (Persero) Tbk (BBNI), dan Bank Danamon Indonesia Tbk (BDMN) diukur pada periode 2010 2012. Hanya Bank Negara Indonesia (Persero) Tbk (BBNI) yang mengalami kinerja keuangan yang baik menggunakan Du Pont System.

Berikut penelitian yang dilakukan Lianto (2013), menjelaskan bahwa bahwa setelah menganalisis laporan keuangan dua perusahaan rokok tersebut selama tiga tahun, maka penulis dapat menyimpulkan bahwa berdasarkan rata-rata Return On Invesment (ROI), rata-rata Profit Margin (PM), dan rata-rata Total Assets Turn Over (TATO), selama tahun 2008-2010 menunjukkan bahwa PT. Hanjaya Mandala Sampoerna, memiliki kinerja keuangan yang lebih baik dibandingkan PT. Gudang Garam.

Pada penelitian Lestari dan Dziqron (2014), disimpulkan bahwa penerapan $D u$ Pont System dalam mengukur kinerja keuangan perusahaan semen yang terdaftar di Bursa Efek Indonesia selama lima tahun diperoleh rata-rata industri dari Total Asset Turnover 0,87 kali, Net Profit Margin 17,95\%, ROI (Du Pont) 15,91\%. Dari perhitungan PT Holcim Indonesia Tbk mengalami fluktuasi tiap tahunnya dan berada di bawah rata-rata industri. Hal ini menunjukkan bahwa kinerja perusahaan dalam menghasilkan laba kurang baik. Dari perhitungan PT Indocement Tunggal Prakarsa Tbk mengalami fluktuasi tiap tahunnya dan berada di atas rata-rata industri kecuali Total Asset Turnover. Hal ini menunjukkan bahwa kinerja perusahaan dalam menghasilkan laba cukup baik. Dari perhitungan PT Semen Gresik (Persero) Tbk mengalami fluktuasi tiap tahunnya dan berada di atas rata-rata industri. Hal ini menunjukkan bahwa kinerja perusahaan dalam menghasilkan laba semakin baik.

Berdasarkan ketiga hasil penelitian yang telah dilakukan, disimpulkan bahwa $D u$ Pont System digunakan untuk menganalisa laporan keuangan yang terbagi menjadi tiga komponen yakni margin laba bersih, tingkat pengembalian asset dan tingkat pengembalian atas ekuitas atau modal. Hal ini bertujuan untuk melihat kondisi kinerja keuangan perusahaan yang nilai rasionya dibandingkan dengan rasio rata-rata industri, nilai tersebut apakah berada diatas, sama dengan atau diatas rata-rata industri. Penilaian tersebut menunjukkan bahwa kinerja perusahaan dalam menghasilkan laba semakin baik, sedang atau semakin buruk.

\section{KAJIAN PUSTAKA DAN PERUMUSAN PROPOSISI/ HIPOTESIS}

\section{Laporan Keuangan}

Menurut Munawir (2010), laporan keuangan terdiri dari neraca dan suatu perhitungan laba rugi serta laporan mengenai perubahan ekuitas. Neraca tersebut menunjukkan atau menggambarkan jumlah suatu aset, kewajiban dan juga mengenai 
Dinamika Sosial Budaya, Vol 22, No. 2, Desember 2020, pp 174-183

p-ISSN: 1410-9859\& e-ISSN: 2580-8524

http://journals.usm.ac.id/index.php/jdsb

ekuitas dari suatu perusahaan pada tanggal tertentu.

\section{Kinerja Keuangan}

Menurut Rudianto (2013), Kinerja keuangan adalah hasil atau prestasi yang telah dicapai oleh manajemen perusahaan dalam mengelola aset perusahaan secara efektif selama periode tertentu. Kinerja keuangan sangat dibutuhkan oleh perusahaan untuk mengetahui dan mengevaluasi tingkat keberhasilan perusahaan berdasarkan aktivitas keuangan yang telah dilaksanakan.

\section{Rasio Keuangan}

Fahmi (2015), menjelaskan bahwa rasio keuangan adalah rasio yang dapat dipahami sebagai hasil yang diperoleh antara satu jumlah dengan jumlah lainnya. Rasio ini disebut sebagai perbandingan jumlah, dari satu jumlah dengan jumlah lainnya itulah kemudian dilihat perbandingannya. Adapun rasio yang akan digunakan adalah Rasio Likuiditas, Rasio Solvabilitas, Rasio Aktivitas dan Rasio Profitabilitas.

\section{Rasio Likuiditas}

Rasio Likuiditas terdiri dari Rasio Lancar (Current Ratio) dan Rasio Kas (Cash Ratio) (Kasmir, 2015)

a. Rasio Lancar (Current Ratio)

$$
\text { Rasio Lancar }=\frac{\text { Aktiva Lancar }}{\text { Hutang Lancar }}
$$

b. Rasio Kas (Cash Ratio)

$$
\text { Rasio Kas }=\frac{\text { Kas + Bank }}{\text { Hutang Lancar }}
$$

\section{Rasio Solvabilitas}

Rasio Solvabilitas terdiri dari Debt to Assets Ratio, Debt to Equity Ratio dan Times Interest Earned Ratio (Kasmir, 2015) : a. Debt to Assets Ratio

$\mathrm{DAR}=\frac{\text { Total Asset }}{\text { Tebt to Equity Ratio }}$

b. Debt to Equity Ratio

$$
\mathrm{DE} R=\frac{}{\text { Equity }}
$$

c. Times Interest Earned Ratio

$$
\begin{aligned}
& \mathrm{TIER}=\frac{\mathrm{EBIT}}{\text { Biaya Bunga }(\text { Interest })} \\
& \mathrm{TIER}=\frac{\mathrm{EBT}+\text { Bunga }}{\text { Biaya Bunga (Interest })}
\end{aligned}
$$

\section{Rasio Aktivitas}

Rasio Aktivitas terdiri dari Working Capital Turnover (perputaraan modal kerja), Total Assets Turnover dan Fix Assets Turnover.

a. Perputaran Modal Kerja (Working Capital Turnover) Penjualan Bersih

$$
\text { WCT }=\frac{}{\text { Modal Kerja }}
$$

b. Total Assets Turn Over

$$
\text { Penjualan }
$$

$$
\text { TATO }=
$$

c. Fixed Assets Turn Over

$$
\text { FAT }=\frac{\text { Penjualan }}{\text { Total Aktiva Tetap }}
$$

\section{Rasio Profitabilitas}

Rasio profitabilitas terdiri dari Profit Margin (Profit Margin on Sales), Return on Investment (ROI) dan Return on Equity (ROE).

a. Profit Margin (Profit Margin on Sales)

- Untuk margin laba kotor Penjualan bersih - HPP 
Dinamika Sosial Budaya, Vol 22, No. 2, Desember 2020, pp 174-183

p-ISSN: 1410-9859\& e-ISSN: 2580-8524

http://journals.usm.ac.id/index.php/jdsb

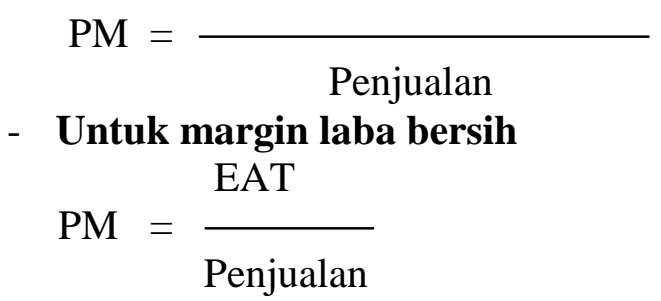

b. Return on Investment (ROI)

$$
\text { ROI }=\frac{\text { NPM }}{\text { Perputaran Aktiva }}
$$

c. Return on Equity (ROE)

$$
\mathrm{ROE}=\frac{\text { EAT }}{\text { Equity }}
$$

\section{Du Pont System}

Husnan dan Pudjiasztuti (2012) mengemukakan bahwa análisis sistem Du Pont menghitung Return on Investment (ROI) didefinisikan sebagai perbandingan antara laba setelah pajak dengan total aktiva. Hal ini dapat dinyatakan dalam bentuk ratio keuangan yakni (1) ROI = Net Profit Margin $\mathrm{x}$ Perputaran Aktiva; (2) Net Profit Margin = Laba sesudah pajak / Penjualan; dan Perputaran Aktiva $=$ Penjualan $/$ Total Aktiva.

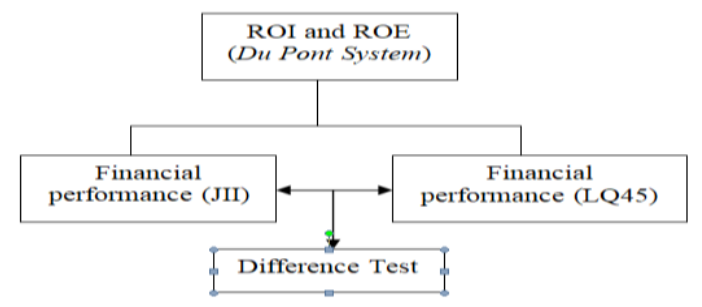

Gambar 1. Model Penelitian

\section{METODE PENELITIAN/DEMENSI PENELITIAN}

Jenis penelitian yang digunakan adalah kausal komparatif. Penelitian ini akan membandingkan kinerja keuangan perusahaan untuk saham Jakarta Islamic Index (JII) dan Indeks LQ45.

Jenis data yang digunakan adalah data sekunder, yaitu data yang diterbitkan oleh Bursa Efek Indonesia. Data sekunder berupa
Neraca per 31 Desember 2014 - 2018 dan Laporan Laba Rugi untuk tahun berakhir tahun $2014-2018$.

Populasi penelitian adalah perusahaan untuk saham Jakarta Islamic Index yang berjumlah 30 emiten dan Indeks LQ45 yang berjumlah 45 emiten. Teknik pengambilan sampel dilakukan dengan menggunakan Purposive Sampling.

Teknik analisa data menggunakan $D u$ Pont System dan Uji Beda (Independent Sample t Test).

\section{HASIL DAN PEMBAHASAN Analisa Du Pont System}

Tabel 1.

\begin{tabular}{|c|c|c|c|c|c|c|c|}
\hline \multirow{2}{*}{\multicolumn{2}{|c|}{ Explanation }} & \multicolumn{5}{|c|}{ Du Pont System } & \multirow{3}{*}{$\begin{array}{r}\text { Average } \\
0,75\end{array}$} \\
\hline & & 2014 & 2015 & 2016 & 2017 & 2018 & \\
\hline \multirow{5}{*}{ JII } & TATO & 0,88 & 0,79 & 0,74 & 0,76 & 0,58 & \\
\hline & NPM & 14,47 & 11,95 & 11,99 & 12,18 & 11,63 & 12,44 \\
\hline & ROI & 10,76 & 8,66 & 9,00 & 9,17 & 7,66 & 9,05 \\
\hline & EM & 2,24 & 2,13 & 1,96 & 1,99 & 2,07 & 2,08 \\
\hline & ROE & 23,20 & 19,40 & 19,81 & 20,01 & 16,21 & 19,73 \\
\hline \multirow{5}{*}{ LQ45 } & TATO & 0,82 & 0,74 & 0,70 & 0,71 & 0,58 & 0,71 \\
\hline & NPM & 15,67 & 13,41 & 14,31 & 12,88 & 14,04 & 14,06 \\
\hline & ROI & 12,98 & 12,12 & 11,65 & 10,76 & 8,77 & 11,26 \\
\hline & EM & 3,99 & 2,20 & 2,20 & 2,40 & 2,37 & 2,63 \\
\hline & ROE & 89,02 & 27,59 & 22.58 & 20,42 & 16,04 & 35,13 \\
\hline
\end{tabular}

Hasil Perhitungan Analisis Du Pont Tahun 2014 - 2018 - Indeks Saham JII dan LQ45

Berdasarkan hasil perhitungan analisa Du Pont periode tahun 2014 - 2018 untuk Indeks Saham JII diperoleh hasil rata-rata Total Assets Turn Over sebesar 0,75 kali, rata-rata Net Profit Margin sebesar 12,44\%, rata-rata Return On Investment sebesar 9,05\%, rata-rata Equity Multiflier sebesar 2,08 kali dan rata-rata Return On Equity sebesar $19,73 \%$.

Sedangkan hasil perhitungan analisa Du Pont periode tahun 2014 - 2018 untuk Indeks Saham LQ45 diperoleh hasil rata-rata Total Assets Turn Over sebesar 0,71 kali, rata-rata Net Profit Margin sebesar 14,06\%, rata-rata Return On Investment sebesar 11,26\%, ratarata Equity Multiflier sebesar 2,63 kali dan rata-rata Return On Equity sebesar 35,13\%. 
Dinamika Sosial Budaya, Vol 22, No. 2, Desember 2020, pp 174-183

p-ISSN: 1410-9859\& e-ISSN: 2580-8524

http://journals.usm.ac.id/index.php/jdsb

Uji Beda - Independent Sample t Test

Tabel 2. Hasil Uji Independent Sample t Test - ROI

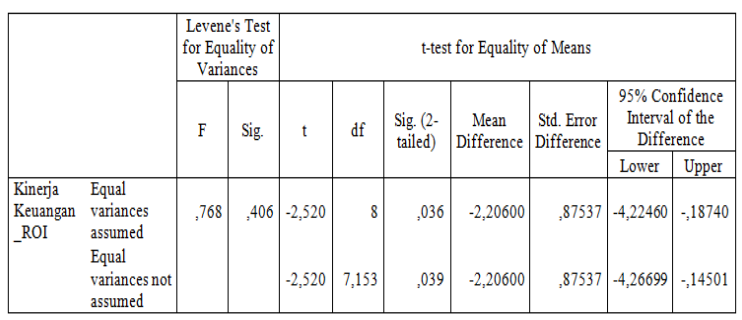

Berdasarkan hasil uji beda, menunjukkan bahwa nilai signifikan Levene's Test for Equality of Variances kinerja keuangan yang diukur dengan ROI sebesar 0,406 lebih besar dari 0,05 maka dapat diartikan bahwa varians data antara emiten untuk jenis saham JII dan LQ45 adalah homogen atau sama (Surjaweni, 2014). Sehingga penafsiran didasarkan pada nilai Sig. (2-tailed) pada bagian Equal Varians Assumed yang diketahui nilai Sig. (2-tailed) sebesar 0,036 lebih kecil dari 0,05 maka sebagaimana dasar pengambilan keputusan dalam uji Independent Sample t Test bahwa Ho ditolak dan Ha diterima, oleh karena itu disimpulkan bahwa ada perbedaan yang signifikan (nyata) antara kinerja keuangan yang diukur dengan ROI untuk jenis saham JII dan LQ45.

Tabel 3. Hasil Uji Independent Sample t Test - ROE

\begin{tabular}{|c|c|c|c|c|c|c|c|c|c|c|}
\hline & \multicolumn{2}{|c|}{$\begin{array}{c}\text { Levene's Test } \\
\text { for Equality of } \\
\text { Variances } \\
\end{array}$} & \multicolumn{7}{|c|}{ t-test for Equality of Means } \\
\hline & & \multirow[t]{2}{*}{$\mathrm{F}$} & \multirow[t]{2}{*}{ Sig. } & \multirow[t]{2}{*}{$t$} & \multirow[t]{2}{*}{ df } & \multirow[t]{2}{*}{$\begin{array}{l}\text { Sig. (2- } \\
\text { tailed) }\end{array}$} & \multirow[t]{2}{*}{$\begin{array}{l}\text { Mean } \\
\text { Difference }\end{array}$} & \multirow[t]{2}{*}{$\begin{array}{l}\text { Std. Error } \\
\text { Difference }\end{array}$} & \multicolumn{2}{|c|}{\begin{tabular}{|c}
$95 \%$ Confidence \\
Interval of the \\
Difference
\end{tabular}} \\
\hline & & & & & & & & & \begin{tabular}{|l|} 
Lower \\
\end{tabular} & \begin{tabular}{|l|} 
Upper \\
\end{tabular} \\
\hline \multirow[t]{2}{*}{\begin{tabular}{|l|} 
Kineja \\
Keuangan \\
_ROE
\end{tabular}} & $\begin{array}{l}\text { Equal } \\
\text { variances } \\
\text { assumed }\end{array}$ & 3,421 & ,102 & $\mid-1,300$ & 8 & ,230 & $-3,40400$ & 2,61843 & $-9,44211$ & 2,63411 \\
\hline & $\begin{array}{l}\text { Equal } \\
\text { yariances not } \\
\text { assumed }\end{array}$ & & & $|-1,300|$ & 5,671 & .244 & $-3,40400$ & 2,61843 & $-9,90223$ & 3,09423 \\
\hline
\end{tabular}

Berdasarkan hasil uji beda, menunjukkan bahwa nilai signifikan Levene's Test for Equality of Variances kinerja keuangan yang diukur dengan ROE sebesar 0,102 lebih besar dari 0,05 maka dapat diartikan bahwa varians data antara emiten untuk jenis saham JII dan LQ45 adalah homogen atau sama (Surjaweni, 2014). Sehingga penafsiran didasarkan pada nilai Sig. (2-tailed) pada bagian Equal Varians Assumed yang diketahui nilai Sig. (2-tailed) sebesar 0,230 lebih besar dari 0,05 maka sebagaimana dasar pengambilan keputusan dalam uji Independent Sample t Test bahwa Ha ditolak dan Ho diterima, oleh karena itu disimpulkan bahwa tidak ada perbedaan yang signifikan (nyata) antara kinerja keuangan yang diukur dengan ROE untuk jenis saham JII dan LQ45.

Kinerja keuangan perusahaan untuk saham Jakarta Islamic Index (JII) dan Indeks LQ45 dengan menggunakan $\mathrm{Du}$ Pont System.

Menurut Kasmir (2015), kinerja keuangan yang diukur dengan Return on Investment (ROI) yakni rasio yang menunjukkan hasil (return) atas jumlah aktiva yang digunakan dalam perusahaan. ROI juga merupakan suatu ukuran tentang efektivitas manajemen dalam mengelola investasinya. Kasmir (2015) juga menjelaskan kinerja keuangan yang diukur dengan Return on Equity (ROE) adalah rasio untuk mengukur laba bersih sesudah pajak dengan modal sendiri. Rasio ini menunjukkan efisiensi penggunaan modal sendiri. Semakin tingggi rasio ini, semakin baik.artinya, posisi pemilik perusahaan semakin kuat, demikian pula sebaliknya.

Du Pont System menurut Gitman (2009) adalah analisis yang digunakan untuk membedah laporan keuangan perusahaan dan untuk menilai kondisi keuangan yakni menggabungkan laporan laba rugi dan neraca menjadi dua langkah ringkasan profitabilitas : Return on Assets (ROA) dan Return on Equity (ROE). Menghitung Return on Investment (ROI) menggunakan análisis sistem Du Pont menurut Husnan dan Pudjiastuti (2012) didefinisikan sebagai 
Dinamika Sosial Budaya, Vol 22, No. 2, Desember 2020, pp 174-183

p-ISSN: 1410-9859\& e-ISSN: 2580-8524

http://journals.usm.ac.id/index.php/jdsb

perbandingan antara laba setelah pajak dengan total aktiva. Hal ini dapat dinyatakan dalam bentuk ratio keuangan yakni (1) $\mathrm{ROI}=$ Net Profit Margin x Perputaran Aktiva; (2) Net Profit Margin = Laba sesudah pajak / Penjualan; dan Perputaran Aktiva = Penjualan / Total Aktiva.

Berdasarkan hasil perhitungan analisa Du Pont periode tahun 2014 - 2018 untuk Indeks Saham JII mampu menghasilkan laba bersih setelah pajak dari total aktiva dengan rata-rata Return On Investment berada di bawah rata-rata industri bahwa kinerja perusahaan dalam menghasilkan laba kurang baik dan rata-rata Return On Equity lebih dari satu hal ini menunjukkan semakin efektif dan efisien penggunaan ekuitas perusahaan untuk menghasilkan pendapatan. Sedangkan hasil perhitungan analisa $\mathrm{Du}$ Pont periode tahun 2014 - 2018 untuk Indeks Saham LQ45 mampu menghasilkan laba bersih setelah pajak dari total aktiva dengan rata-rata Return On Investment berada di bawah rata-rata industri menunjukkan bahwa perputaran aktiva, hal ini menunjukkan bahwa kinerja perusahaan dalam menghasilkan laba kurang baik, dan rata-rata Return On Equity lebih dari satu hal ini menunjukkan semakin efektif dan efisien penggunaan ekuitas perusahaan untuk menghasilkan pendapatan.

Hasil penelitian ini sejalan dengan penelitian yang dilakukan oleh Lianto (2013) dan sesuai dengan teori yang dikemukakan oleh Kasmir (2015), Gitman (2009), Husnan $\&$ Pudjiastuti (2012) serta Kasmir (2008).

\section{Perbedaan kinerja keuangan perusahaan untuk saham Jakarta Islamic Index (JII) dengan Index LQ45.}

Return on Invesment adalah rasio untuk menggambarkan seberapa besar laba bersih yang didapatkan perusahaan dari seluruh kekayaan yang dimilikinya. Terdapat dua faktor yang dapat mempengaruhi ROI yaitu perputaran aktiva yang di pergunakan untuk operasional perusahaan dan Profit Margin dan besarnya keuntungan operasional yang terlihat dari persentase dan jumlah penjualan bersih (Husnan, 2016).

Return On Equity untuk mengukur laba bersih setelah pajak dengan modal sendiri. Rasio Return On Equity ini menunjukan efisiensi penggunaan modal sendiri. Apabila rasio ini semakin tinggi, maka semakin baik. Itu artinya posisi perusahaan akan semakin kuat, begitu pula dengan sebaliknya (Kasmir, 2015).

Berdasarkan hasil penelitian disimpulkan bahwa ada perbedaan yang signifikan (nyata) antara kinerja keuangan yang diukur dengan ROI untuk jenis saham JII dan LQ45 hal ini menggambarkan terdapat perbedaan laba bersih yang didapatkan perusahaan dari seluruh kekayaan yang dimilikinya. Sedangkan kinerja keuangan yang diukur dengan ROE untuk jenis saham JII dan LQ45 tidak terdapat perbedaan yang signifikan (nyata) hal ini menunjukkan bahwa tidak terdapat perbedaan laba bersih setelah pajak yang dihasilkan perusahaan dan tidak terdapat perbedaan efisiensi penggunaan modal sendiri oleh perusahaan.

Hasil penelitian ini sejalan dengan penelitian yang dilakukan oleh Hajar \& Priantinah (2017) dan sesuai dengan teori yang dikemukakan oleh Kasmir (2015) dan Husnan (2016).

\section{SIMPULAN}

Berdasarkan analisis dan pembahasan hasil pengujian hipotesis yang telah dilakukan dapat diajukan beberapa kesimpulan yaitu sebagai berikut :

1. Hasil perhitungan analisa Du Pont periode tahun 2014 - 2018 untuk Indeks Saham JII diperoleh rata-rata Return On Investment berada di bawah rata-rata industri hal ini menunjukkan bahwa kinerja perusahaan dalam menghasilkan laba kurang baik dan 
Dinamika Sosial Budaya, Vol 22, No. 2, Desember 2020, pp 174-183

p-ISSN: 1410-9859\& e-ISSN: 2580-8524

http://journals.usm.ac.id/index.php/jdsb

rata-rata Return On Equity lebih dari satu hal ini menunjukkan semakin efektif dan efisien penggunaan ekuitas perusahaan untuk menghasilkan pendapatan.

2. Hasil perhitungan analisa Du Pont periode tahun 2014 - 2018 untuk Indeks Saham LQ45 diperoleh rata-rata Return On Investment berada di bawah rata-rata industri menunjukkan bahwa perputaran aktiva, hal ini menunjukkan bahwa kinerja perusahaan dalam menghasilkan laba kurang baik, dan rata-rata Return On Equity lebih dari satu hal ini menunjukkan semakin efektif dan efisien penggunaan ekuitas perusahaan untuk menghasilkan pendapatan.

3. Hasil penelitian disimpulkan bahwa terdapat perbedaan yang signifikan (nyata) antara kinerja keuangan yang diukur dengan ROI untuk jenis saham JII dan LQ45 hal ini menggambarkan terdapat perbedaan laba bersih yang didapatkan perusahaan dari seluruh kekayaan yang dimilikinya. Sedangkan kinerja keuangan yang diukur dengan ROE untuk jenis saham JII dan LQ45 tidak terdapat perbedaan yang signifikan (nyata) hal ini menunjukkan bahwa tidak terdapat perbedaan laba bersih setelah pajak yang dihasilkan perusahaan dan tidak terdapat perbedaan efisiensi penggunaan modal sendiri oleh perusahaan.

\section{DAFTAR PUSTAKA}

Agus Harjito dan Martono. 2010. Manajemen Keuangan. Yogyakarta: Ekonisia

Agus Sartono. 2012. Manajemen Keuangan : Teori dan Aplikasi. Edisi 4. BPFE. Yogyakarta.

Brigham dan Houston. 2010. Dasar-dasar Manajemen Keuangan Buku 1. (Edisi 11). Jakarta : Salemba Empat.
Fahmi, Irham. 2015. Analisis Laporan Keuangan, Cetakan Ke-5. Bandung : Alfabeta.

Gitman, Lawrence. 2009. Principles of Manajerial Finance. United States: Pearson Addison Wesley.

Ghozali, Imam. 2016. Aplikasi Analisis Multivariete Dengan Program IBM SPSS 23 (Edisi 8). Cetakan ke VIII. Semarang : Badan Penerbit Universitas Diponegoro.

Harahap, Sofyan Syafri. 2015. Analisis Kritis atas Laporan Keuangan. Edisi 1-10. Jakarta: Rajawali Pers

Kasmir.2008. Bank dan Lembaga Keuangan Lainnya. Edisi Revisi 2008. Jakarta: PT.RAJAGRAFINDO PERSADA.

Kasmir. 2015. Analisis Laporan Keuangan. Jakarta : PT Raja Grafindo Persada

Lestari, Wuryaningsih Dwi Lestari \& Moh Dziqron. 2014. Penerapan Du Pont System Untuk Mengukur Kinerja Perusahaan. (Studi Pada Perusahaan Semen Yang Terdaftar Di BEI Tahun 2007-2011). Seminar Nasional dan Call for Paper (Sancall 2014): Research Methode And Organizational Studies. ISBN : 978602-70429-1-9. Hlm. 327-341. Universitas Muhammadiyah Surakarta

Lesmana, Theresia. 2013. Penilaian Kinerja Keuangan 5 Perusahaan Perbankan Menggunakan Du Pont System. Binus Business Review. Vol. 4 No. 2 November 2013 : 834-840. BINUS University 
Dinamika Sosial Budaya, Vol 22, No. 2, Desember 2020, pp 174-183

p-ISSN: 1410-9859\& e-ISSN: 2580-8524

http://journals.usm.ac.id/index.php/jdsb

Lianto, David. 2013. Penilaian Kinerja Keuangan Perusahaan Menggunakan $\mathrm{Du}$ Pont System. Jurnal JIBEKA, Volume 7, No. 2, Agustus $2013: 25-31$. Universitas Ma Chung

Munawir, S. 2012. Analisis laporan Keuangan. Edisi keempat. Cetakan KelimaBelas. Yogyakarta : Liberty

Weston, J. Feed dan Thomas E. Copeland.2010. Manajemen Keuangan. Jakarta: Binarupa Aksara

Rahardjo. Budi. 2007. Keuangan Dan Akuntansi. Graha Ilmu. Yogyakarta

Rudianto. 2013. Akuntansi Manajemen Informasi untuk Pengambilan Keputusan Strategis. Jakarta: Erlangga

Santoso, Singgih. 2014. Statistik Multivariat. Edisi Revisi.Jakarta: PT Elex Media Komputindo.

Siti Hajar dan Denies Priantinah. 2017. Perbandingan Kinerja Keuangan Perusahaan JII Dengan LQ45 Dan Pengaruhnya Terhadap Return Saham. Jurnal Profita Edisi 8 Tahun 2017

Sujarweni, V. Wiratna. 2014. Metode Penelitian: Lengkap, Praktis, dan Mudah Dipahami. Yogyakarta: Pustaka Baru Press.

Sutrisno. (2009), Manajemen Keuangan Teori, Konsep dan Aplikasi, Edisi Pertama, CetakanKetujuh, Penerbit Ekonisia, Yogyakarta
Sugiyono. (2017). Metode Penelitian Kuantitatif, Kualitatif, dan $R \& D$. Bandung : Alfabeta, CV.

Suad Husnan dan Enny Pudjiastuti. 2012. Dasar -Dasar Manajemen Keuangan. Edisi Keenam Cetakan Pertama. Yogyakarta : UPP STIM YPKN.

Suad Husnan. 2006. Dasar-dasar Teori Portofolio dan Analisis Sekuritas. Yogyakarta. Penerbit : UPP AMP YKPN. 